\title{
The Effects of Augmented Reality to Motivation and Performance in EFL Vocabulary Learning
}

\author{
Cheng-Chang Tsai
}

Department of Applied Foreign Languages, Nan Kai University of Technology, Taiwan (R.O.C.),a0955377623@gmail.com

The main purpose of this study was to examine the differences in students' English vocabulary learning performance as well as the instructional materials motivation, comparing the traditional lecturing method and the Augmented Reality method. This study adopted an unequal pre-test and post-test experimental design. Overall, there were a total of 42 students in two fifth grade classes in an elementary school in Central Taiwan who served as the participants of this study. Data were collected by English vocabulary tests, an instructional materials motivation questionnaire, and structured interviews. Data analyses were mixed with the quantitative and qualitative methods. The results showed that the instructional materials motivation and performance of the students taught using AR were superior to those of students taught using the traditional lecturing method. In addition, the qualitative findings of this study identified the opportunities and obstacles when adopting AR and using the traditional lecturing methods to learn English vocabulary. These findings might provide useful insights toward the successful application of English instruction in the educational realm for elementary school EFL students and teachers in Taiwan.

Keywords: English learning, performance, motivation, augmented reality, EFL

\section{INTRODUCTION}

In light of the trend of the global village, English fluency is an ability that every citizen should have today. However, when students learn English, they often suffer from anxiety, resulting in low motivation and poor effectiveness in English learning. In the traditional English vocabulary learning process, students can only memorize words by means of boring recitation and repetitive practice. This mechanical method greatly reduces learners' curiosity and sense of novelty about learning a foreign language, making their original learning interest and motivation disappear with the boring recitations (Alqahtani, 2015). The integration of science and technology into the development of English instruction has changed the application of science and technology to English learning. In many English teaching scenarios, IT tools and multimedia graphic

Citation: Tsai, C-C. (2020). The Effects of Augmented Reality to Motivation and Performance in EFL Vocabulary Learning. International Journal of Instruction, 13(4), 987-1000. https://doi.org/10.29333/iji.2020.13460a 
information have been employed to make teaching vivid and fun (Al-Emran et al., 2016; Alrasheedi et al., 2016). In the traditional method of cramming teaching, students generally become bored with English vocabulary learning, resulting in poor academic performance. In contrast, games have connotations which can boost high learning motivation, enabling students to actively participate, and enhance students' interest in learning (Furio et al., 2015; Cheng, 2017) For the present e-generation, due to the rapid development of mobile devices, a new mobile learning model has been created to make the educational environment more diverse. The integration of game learning concept has also improved students' English motivation and interest (Amara et al., 2016).

Vocabulary is an important component of linguistic knowledge and a vital element for constructing mental syntax (Fromkin et al., 2007). Without sufficient vocabulary, languages cannot be used to convey personal thoughts and communication with others. Consequently, a foreign scholar, Lewis (1993), believes that vocabulary teaching is very important, emphasizing the importance of vocabulary teaching in English learning. Lewis (1993) also stated that $80 \%$ human knowledge is sourced through vision, so students' learning effect varies based on different sensory memories. In other words, learners are less likely to understand unfamiliar languages or contents, but visual assistance will help their understanding in learning. This study intends to be targeted at Taiwan's elementary school students, aiming to explore how to help learners effectively use the learning strategies with 3D dynamic images of Augmented Reality to learn English vocabulary, so as to improve learners' learning outcomes. The research questions are as follows:

1. Is there any significant difference in English vocabulary learning performances between elementary school students who are using the Augmented Reality and those adopting the traditional lecturing method?

2. What is the difference in the instructional materials motivation survey (inclusive of attention, confidence, satisfaction, and relevance domains) between students who are using the Augmented Reality and those adopting the traditional lecturing method?

3. What are opportunities and obstacles for elementary school students when they use the AR method and the traditional lecturing methods to learn English vocabulary?

\section{LITERATURE REVIEWS}

\section{The Importance of English Vocabulary Learning}

Alqahtani (2015) said that the first step in learning a second language is to learn vocabulary. Hyso and Tabaku (2011) also pointed out that in the process of English learning, students must accumulate enough vocabulary to build their basic functional ability of foreign languages, or they will encounter learning obstacles in English learning skills such as listening, speaking, reading, and writing. It can be seen that learning English vocabulary is the most significant and challenging task. Lin, Wang, \& Du (2013) indicated that students often encounter bottlenecks when learning English vocabulary and do not know which method can be used to increase their English vocabulary size. Most Chinese students learn English vocabulary by rote while only a few students will employ other strategies to enlarge their English vocabulary size. 
Alqahtani (2015) suggested that language learning strategies be taught by teachers' instruction, and the vocabulary memory strategy should be incorporated into the curriculum and teaching. By doing so, students can be guided to understand the importance of learning strategies as well as be taught how to use these learning strategies, so that they are able to enhance their learning effectiveness and yield a better result with less effort. Therefore, when learning English vocabulary, if learners can adopt English learning strategies which suit them well, these strategies can benefit the learners in learning English vocabulary. English vocabulary size will affect readers' reading comprehension ability. Accordingly, if the reader's English vocabulary can be improved in breadth and depth, students can understand the meaning of vocabulary and further understand the meaning of sentences and text content, so that learners will not remain illiterate in English reading (Lin et al., 2013). As a result, vocabulary plays an important role in the process of English learning whose slight change can affect everything else, leading to an inseparable relationship with the whole network.

\section{Using Augmented Reality to Learn English Vocabulary in Mobile Learning}

The advent of personal devices, such as mobile phones, iPads, and so on, enable learners' communication to be more convenient than ever. The digital learning method has gradually changed from online learning to "mobile learning" and "ubiquitous learning". The high mobility of mobile equipment reduces the original limitations of digital learning and makes it easier for learners to learn anytime and anywhere (Yousafzal et al., 2016). In the past, the computer-assisted learning method was often constrained by the location of the computer or the weight of the notebook computer. The cellphone-assisted learning method is suitable for learning, with fast and lifelong features, especially those most appropriate for language learning (Kim \& Hyun, 2016).

In recent years, with the advancement of network technology, interactions between people have undergone many changes. The network breaks the boundaries of time and space, extending from the classroom to the outside of the classroom and expanding students' learning method and field. Mobile learning has continuously received attention in recent years because its ascendancy technology has had a very large impact on society (Karimi, 2016). With the rise of mobile devices, the user is no longer confined to a fixed indoor space, but we can access and read information from any location instead. The advance of wireless communication technology has diversified the functions of mobile devices. The learning method based on mobile technology is gradually highlighted because it has more advantages than the e-learning done by computers in the past (Amara et al., 2016).

Traditional learning method relies on paper instructional materials. With the development of digital technology, learning is no longer limited to paper instructional materials. Establishing effective learning for students is a priority. As the mobile network technology rapidly develops, the functions provided by mobile devices have changed people's lifestyles incrementally. In particular, the technology of AR can be used to combine the real world and the virtual world, bringing more entertainment and functionality to users (Abate \& Nappi, 2016; Challenor \& Ma, 2019). AR technology can be also applied to the auxiliary instruction for learning, making the learning process 
more vivid. In recent years, many studies of intelligent devices have begun to focus on children. Combining learning with cellphone applications (APPs) not only brings entertainment and fun but also enables children to learn and further realize the value of learning and education. The so-called AR is a way to add virtualization technology to the user's sensory perception and then observe the world (El-Kabtane et al., 2016). AR can provide us with information that is not directly known in reality. AR is regarded as a new type of information technology which breaks away from the traditional image display method and is also a way to observe the world by combining virtualization technology (Cabero \& Barroso, 2016). Such a new technology gradually integrated with the real human life can be viewed as a new source of innovation for today's entertainment business, commercial advertising, and digital learning. If mobile learning can integrate AR, it can better enhance a learner's interest in learning (Richardson, 2016; Zhang, 2018).

Some Taiwanese researchers have begun using the technology of AR and English learning results to do related teaching research. For instance, Lin (2009) applied AR to his teaching research and helped elementary school student's English learning with AR. The results have shown that such teaching effects apparently exceed the effects of the general traditional teaching methods. Besides that, it had a significant influence on English learning for the students of the highest and the lowest English levels; students of different genders all received remarkable learning results. Huang (2009) also adopted AR to improve students' English vocabulary learning, expecting that the AR applications could enhance students' positive learning outcomes. It is obvious that the teaching method of AR was efficient in promoting English learning proficiency for elementary school English learners.

\section{METHOD}

\section{Participants}

The study participants were 42 fifth grade students at an elementary school located in Central Taiwan. The participants ranged between 11 and 12 years of age and were recruited from two classes. The English proficiencies of the students in both classes were roughly similar, and students were taught by the same teacher. One class served as the experimental group $(\mathrm{n}=22)$ and the other class served as the control group $(\mathrm{n}=20)$. This experimental activity lasted for four weeks during the regular semester, and the teaching time was around 30 minutes each week. Prior to the experiment, the teacher was asked to take 2-hours of training to learn how to display the AR system.

\section{Design and Implementation Procedure for the Instructional Experiment Activity}

This study adopted the nonequivalent pre-test and post-test design of the quasiexperimental research method. A "random sampling" was used to draw one class of students as the experimental group conducting the English vocabulary teaching experiment with AR, and the other class as the control group performing English vocabulary teaching in a traditional lecturing way. In the control group, when the teacher says "book (shūběn)", the students need to repeat the word, "book (shūběn)". The teaching tools used by the instructors are only traditional English vocabulary and Chinese translation. Every student had a iPad that provided by the school authorities to 
the experimental group. In the experimental group, the English vocabulary teaching model using AR means that teacher used iPads that were provided to the school authorities to download pictures from the website, QuiverVision, and then ask the learners to manually paint the downloaded pictures with their favorite colors. Finally, teachers downloaded apps from their mobile learning devices and integrated the pictures with the $3 \mathrm{D}$ visual effects and audio by means of AR to help students learn the English vocabulary associated with the pictures (See Figure 1 and 2). During the experiment period, the teacher asked all participants to avoid studying English vocabulary of the teaching contents at home and after school. Because of this, other variables or interferences were eliminated, so the validity and reliability for the experiment were increased.

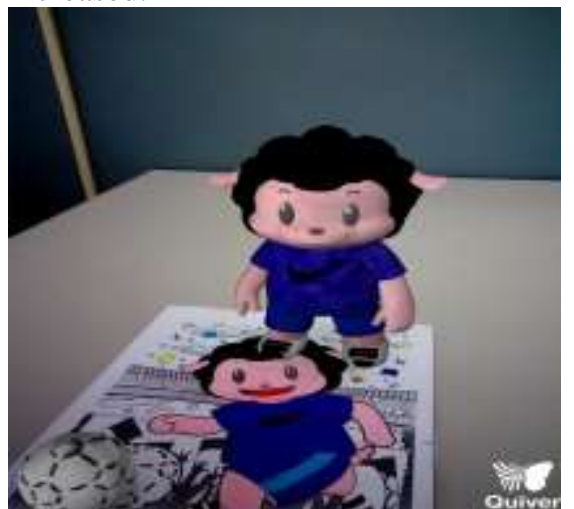

Figure 1

AR presented in 3D

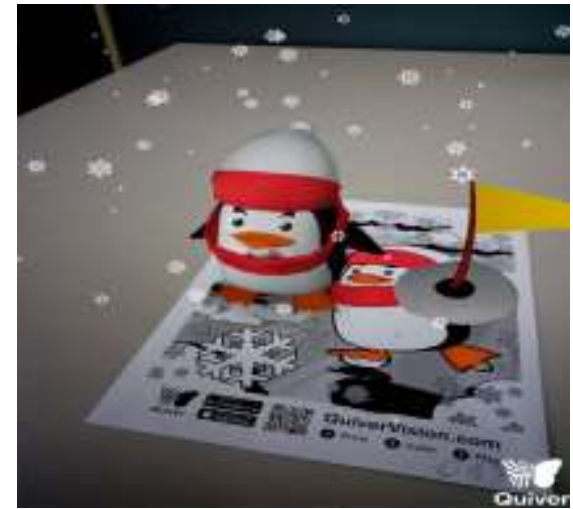

Figure 2

AR presented in $3 \mathrm{D}$

\section{Data Collection}

This study adopted the nonequivalent pre-test and post-test design of the quasiexperimental research method, divided into experimental group and control group. At the beginning of the experiment, both classes were tested with the "Instructional Materials Motivation Survey" and the "English Vocabulary Competence Pre-test" to collect pre-test scores for "Instructional Materials Motivation Survey" and English vocabulary competence. After the experiment, all subjects were tested again with the "Instructional Materials Motivation Survey" and the "English Vocabulary Competence Post-test" to collect the post-test scores of the instructional materials motivation and learning outcomes. In the qualitative approach, this project adopted structural interviews, requesting students' comments and opinions about the AR teaching method and the traditional lecturing method.

\section{English Vocabulary Test}

The content of this test paper is to extend the relevant vocabulary from the downloaded pictures of QuiverVision as the scope of learning. The website, QuiverVision, provides relevant pictures and apps for teachers to download. After teachers print out pictures, students can use color pens to paint them with their favorite colors. Students can download the apps to make these pictures exhibit the visual effects of AR and combine 
them with English vocabulary learning, further enhancing their interest and motivation in learning English vocabulary.

The teacher uses the English vocabulary related to the pictures as the test content (See Figure 3). This test paper is used as the main test content for students' pre-test and posttest with a total of 25 multiple-choice questions, and a total possible score is 100 . In addition, both classes were given the pre-test prior to any instruction. The English vocabulary test was given after 4 weeks of instruction; the post-test was carried out in the $5^{\text {th }}$ week.)

\begin{tabular}{ll}
\hline week & Teaching Contents \\
\hline 1 & robot/mask/cape/bow/carrot/tank/top/ \\
skirt/binoculars
\end{tabular}

Figure 3

English vocabulary test contents

\section{In-Class Worksheet}

Depending on the instructional method, the in-class worksheet will be designed in two different ways:

(1) The instructional method of the traditional vocabulary teaching: mechanically repeating the practice of Chinese-English vocabulary translation in teaching without any picture prompts.

(2) The instructional method of teaching vocabulary with Augmented Reality: integrating the Augmented Reality effects (such as 3D animation, multimedia, etc.) to help students learn through play.

\section{Questionnaire}

The questionnaire used in this project was based on the Instructional Materials Motivation Survey proposed by Keller (1987). The purpose of this questionnaire is to 
investigate students' learning motivation through different instructional materials. The questionnaire consists of 29 questions, including attention, confidence, satisfaction, and relevance domians. The answer options are: Strongly Agree (5 points), Agree (4 points), Neutral (3 points), Disagree (2 points), and Strongly Disagree (1 point). Concerning questionnaire reliability, this study adopted Cronbach's alpha to assess the internal consistency of the questionnaire. The Cronbach's alpha for each sub-dimension was $0.80,0.82,0.81$, and 0.83 , respectively, and for the overall questionnaire was 0.82 . The Cronbach's alpha was required to be above 0.80 for all questionnaire dimensions to indicate good reliability.

\section{Data Analysis}

In order to analyze the study results, an independent samples t-test was conducted to evaluate effects between the control group (traditional lecturing method) and experimental group (the teaching method of AR) group on students' English vocabulary learning in terms of pre-test and post-test. In addition, an independent samples t-test was also adopted to evaluate similarities or differences between the control group (traditional lecturing method) and experimental group (the teaching method of AR) based on the results of the instructional materials motivation survey, inclusive of attention, confidence, satisfaction, and relevance domains with respect to pre-test and post-test.

This research aims to understand the opportunities and obstacles which elementary school learners encounter when using the AR method and the traditional lecturing method to learn English vocabulary. The structured interviews were used for the qualitative data collection, and the interview questions are as follows: "What are opportunities for elementary school students when they use the AR method to learn English vocabulary?", "What are obstacles for elementary school students when they use the AR method to learn English vocabulary?" "What are opportunities for elementary school students when they use the traditional lecturing method to learn English vocabulary?", "What are obstacles for elementary school students when they use the traditional lecturing method to learn English vocabulary?" A total of eight students in the experimental group were selected as interviewees based on purposive sampling. For purposes of comparison, there were also eight participants in the control group who were selected as interviewees based on purposive sampling. Once completing the structured interviews, the researcher started sorting transcripts which must completely present the intentions of the interviewees. Next, the transcripts are analyzed by means of the ground theory, which mainly focuses on data itself; gradually useful patterns are discovered from the data with scientific methods, and then they are categorized and compared repetitively until no new concept shows up, in order to establish the initial theory.

In terms of the interview analyses, thematic analysis was used for identifying, analyzing and reporting themes within the data, and was also used to diagnose the opportunities and obstacles issues stemming from the critical and representative phenomena in the data. Based on the criteria that data within themes should cohere together meaningfully, the differences between four themes should be identifiable and distinguishable. 


\section{FINDINGS}

An independent samples t-test was conducted to evaluate effects between the control group (traditional lecturing method) and the experimental group (the teaching method of AR) on students' English vocabulary learning performances. The results are presented in Table 1 and 2.

An independent samples t-test was performed to assess the homogeneity of variances; the results were insignificant, indicating that pre-test scores for the two groups did not differ significantly. Thus, there were no significant differences between the experimental and control groups in their pre-English vocabulary test, due to $\mathrm{t}(41)=2.00, \mathrm{p}=0.052$ (See Table 1). By contrast, there were significant differences between the experimental and control groups in their post-English vocabulary tests, due to $t(41)=8.14, p<0.0001$. In terms of their English vocabulary scores, the experimental group $(\mathrm{M}=76.10, \mathrm{SD}=12.05)$ was much higher than the control group ( $\mathrm{M}=41.80, \mathrm{SD}=11.05)$ (See Table 2). In other words, performances resulting from the teaching method of AR were better than the performances obtained by the traditional method regarding English vocabulary learning.

An independent samples t-test was also performed to assess the homogeneity of variances; the results were insignificant, indicating that pre-test scores for the two groups did not differ significantly in the instructional materials motivation questionnaire. Therefore, there were no significant differences between the experimental and control groups shown in their instructional materials motivation survey (inclusive of attention, confidence, satisfaction, and relevance domains) on the pre-test. The t value for each sub-dimension was $0.42,1.70,0.39$, and 0.08 , respectively, $\mathrm{p}>0.05$ (See Table $3)$. By contradistinction, there were significant differences between the experimental and control groups based on the results of their instructional materials motivation survey (inclusive of attention, confidence, satisfaction, and relevance domains) on the posttests. The $\mathrm{t}$ value for each sub-dimension was 20.02, 18.40, 12.60, and 12.90, respectively, $\mathrm{p}<0.0001$ (See Table 4). The results of the study have shown that students preferred using AR to the traditional method of learning English vocabulary with respect to attention, confidence, satisfaction, and relevance domains.

Table 1

A Comparison between the Control and Experiment Groups in the Pre-English Vocabulary Test

\begin{tabular}{lllll}
\hline Group & Mean & SD & T-value & $P$-value \\
\hline Control & 24.8 & 9.66 & 2.00 & 0.052 \\
Experiment & 30.0 & 7.24 & & \\
\hline
\end{tabular}

Table 2

A Comparison between the Control and Experiment Groups in the Post-English Vocabulary Test

\begin{tabular}{lllll}
\hline Group & Mean & SD & T-value & $P$-value \\
\hline Control & 41.8 & 11.05 & 8.14 & $<0.0001$ \\
Experiment & 76.1 & 12.05 & & \\
\hline
\end{tabular}


Table 3

A Comparison between the Control and Experiment Groups on the Pre-Test for the Survey

\begin{tabular}{llllll}
\hline Domain & Group & $\mathrm{M}$ & $\mathrm{SD}$ & T-value & $P$-value \\
\hline \multirow{2}{*}{ attention } & Control & 1.84 & 0.262 & 0.42 & 0.673 \\
& Experiment & 1.81 & 0.272 & & \\
\multirow{2}{*}{ confidence } & Control & 1.54 & 0.288 & 1.70 & 0.097 \\
& Experiment & 1.71 & 0.358 & & \\
\multirow{2}{*}{ satisfaction } & Control & 1.93 & 0.358 & 0.39 & 0.698 \\
& Experiment & 2.00 & 0.539 & & \\
relevance & Control & 1.86 & 0.592 & 0.08 & 0.939 \\
& Experiment & 1.85 & 0.629 & & \\
\hline
\end{tabular}

Table 4

A Comparison between the Control and Experiment Groups on the Post-Test for the Survey

\begin{tabular}{llllll}
\hline Domain & Group & M & SD & T-value & $P$-value \\
\hline \multirow{2}{*}{ attention } & Control & 2.19 & 0.321 & 20.02 & $<0.0001$ \\
& Experiment & 3.89 & 0.227 & & \\
\multirow{2}{*}{ confidence } & Control & 2.21 & 0.256 & 18.40 & $<0.0001$ \\
& Experiment & 3.95 & 0.373 & & \\
\multirow{2}{*}{ satisfaction } & Control & 2.13 & 0.494 & 12.60 & $<0.0001$ \\
& Experiment & 3.84 & 0.382 & & \\
\multirow{2}{*}{ relevance } & Control & 1.97 & 0.606 & 12.90 & $<0.0001$ \\
& Experiment & 4.06 & 0.442 & & \\
\hline
\end{tabular}

In terms of the qualitative analysis, the contents of interviews were coded into the themes. As a result, four themes emerged that were consistent among all the participants' responses. The four themes identified were as follows: opportunity factors caused by the use of AR to learn English vocabulary; challenging factors caused by the use of AR to learn English vocabulary; opportunity factors caused by the use of the traditional lecturing method to learn English vocabulary; and challenging factors caused by the use of the traditional lecturing method to learn English vocabulary.

Opportunities for learners to learn English vocabulary by using AR, include:

1. Really exciting and interesting, it was my first time to use such cool equipment to learn English vocabulary and I was full of curiosity and motivation about that (Participant B).

2. Basically, I was attracted to this stuff. First when I moved my iPad on the picture that I painted, a popup image appeared, really amazing! (Participant C)

3. After using AR, I felt that it was really interesting and effective for me to realize my understanding of meanings of words (Participant E)

Obstacles for learners to learn English vocabulary by using AR, include:

1. If I must remember how to learn the word, I do not think AR is a good tool for learning English words. I could probably just write down words a couple of times to memorize them (Participant A). 
2. I felt that learning vocabulary with AR was harmful to our eyes (Participant D).

3. Because of 3D effects, my attention will be distracted by the moving image and I forgot how to remember the vocabulary (Participant F).

Opportunities for learners to learn English vocabulary by using the traditional lecturing method, include:

1. I could gain direct translation from the teacher immediately (Participant M).

2. The teacher's expression and pronunciation were modelled for me to imitate (Participant O).

Obstacles for learners to learn English vocabulary by using the traditional lecturing method include:

1. I felt bored when I was taught with the traditional lecturing method, and I was tired of reciting vocabulary (Participant I).

2. I was under a lot of pressure when repeating the words after the teacher in the classroom (Participant L).

3. I lacked learning motivation and interest when I was in a passive position. (Participant K).

\section{CONCLUSION AND DISCUSSION}

Regarding learning performances, the experimental group exhibited significant improvement. The experimental method indicated that using AR is more beneficial for learning English vocabulary when compared with using the traditional lecturing method. Concerning the instructional materials motivation, the experimental group exhibited significant improvement, too. The experimental method results also indicated that the use of AR is beneficial to learning English vocabulary when compared with using the traditional lecturing method. The results of the study accorded with the findings reported by Jia, Chen, Ding, and Ruan (2012) that pointed out that if instructors provide more interesting learning environments for learners to gain knowledge, then the learning effects are enhanced when using mobile learning because of high motivation. (Liu \& Chu, 2010; Perry, 2015). In addition, the results of this study were also consistent with Lin (2009), Huang (2009), as well as Safar, AI-Jafar, and AI-Yousefi (2017) findings; AR teaching effects apparently excel the effects of the traditional teaching methods and have a positive learning outcome for students. In recent years, the advancement and popularization of mobile technology has made mobile learning become the focus for educators. Since mobile learning has the advantage of being free from time and venue constraints, studying with mobile devices can be done anytime, anywhere. Students can study in the classroom or at home. Because of the portability of mobile devices, learning activities can be carried out at any time, which can enhance learning effects. Tsai, Yu and Hsiao (2012) put forward the educational concept of "edutainment", incorporating the meaning of education in the game, and pointed out that digital game learning could bring positive learning effects. The application of integrating games into learning can not only break the grip of rigid traditional education activities but also effectively improve learning motivation. In other words, learners can improve their motivation and interest by means of games, or learners can have both the learning motivation and the 
learning ability in games at the same time, so that they can learn new knowledge and skills in the process of completing game missions. In addition, Godwin-Jones (2016) developed a place-based mobile game for foreign language learners, and GodwinJones's findings have found how AR could be used effectively in the field of foreign language learning. In conclusion, playing games enables learners to learn in a state of pleasure, and the learning outcomes are usually better than those derived from the traditional learning method. Therefore, for today's generation, the learning model combining multimedia information technology and the use of the Internet has become an inseparable trend of development.

Especially for today's elementary school children with the characteristics of digital indigenous people, their living and learning environment is totally different from their parents' past living environment; it can be said that they are living in a social environment full of multi-technology media applications and integration and own the experience of IT tools' assistance in learning activities. (Inan, et al., 2010). Learning English effectively is an ability that every student should have today. However, when students are learning English, they often regard English learning solely as a serious subject for reading and reciting, so they have a sense of resistance, resulting in diminished English learning capacity. If information technology is effectively incorporated into English learning themes, Augmented Reality and Virtual Reality technologies can be used to combine the real world and the virtual world, bringing English learners entertainment as well as increased functionality. At the same time, learners' concentration and interest in learning English can be enhanced, so that students will no longer resist learning English, and their interest in and motivation for learning English vocabulary can increase. Last but not least, the findings of the qualitative results have identified that although technology might increase learners' motivation and interest, it should take into account possible negative side-effects for young learners in terms of their physical and mental health, such as myopia, learning distraction, as well as other problems indicated in the interviews. We could also comprehend and understand the advantages and disadvantages between AR teaching and traditional teaching methods from the interview analyses. The best teaching method is to strike a balance between a traditional learning method and a non-traditional learning method with respect to foreign language learning. Combing the advantages of the two teaching methods could achieve the best teaching outcomes, improve the English vocabulary proficiencies of the learners' and improve the quality of English vocabulary instruction.

One limitation of the present study was the small number of participants. Because the group consisted of only 42 elementary school students, the results can not be applied generally to all Taiwan EFL elementary school settings. Some directions for future research emerged and as the results of this study have been taken into consideration, it is seen that the results leave some questions to explore further. For instance, how does AR affect EFL learners' among the four English skills (listening, speaking, reading, and writing) in terms of their learning performances? Also how does AR affect EFL learners' among the four English skills (listening, speaking, reading, and writing) in terms of their learning motivation and attitude? 


\section{REFERENCES}

Abate, A., \& Nappi, M. (2016). Augmented reality based framework for multimedia training and learning. Multimedia Tools and Applications, 75(16), 9507-9509.

Al-Emran, M., Elsherif, H., \& Shaalan, K. (2016). Investigating attitudes towards the use of mobile learning in higher education. Computers in Human Behavior, 56, 93-102.

Alqahtani, M. (2015). The importance of vocabulary in language learning and how to be taught. International Journal of Teaching and Education. 3(3), 21-34.

Alrasheedi, M., Capretz, L., \& Raza, A. (2016). Management's perspective on critical success factors affecting mobile learning in higher education institutions. Journal of Educational Computing Research, 54(2), 253-274.

Amara, S., Macedo, J., Bendella, F., \& Santos, A. (2016). Group formation in mobile computer supported collaborative learning contexts: A systematic literature review. Educational Technology, \& Society, 19(2), 258-273.

Cabero, J., \& Barroso, J. (2016). The educational possibilities of augmented reality. Journal of New Approaches in Educational Research, 5(1), 44-50.

Challenor, J., \& Ma, M. (2019). A review of augmented reality applications for history education and heritage visualization. Multimodal Tech and Interaction, 3(39), 1-20.

Cheng, K. H. (2017). Reading an augmented reality book: an exploration of learners' cognitive load, motivation, and attitudes. Australasian J. of Edu. Tech., 33(4), 53-69.

El-Kabtane, H., Sadgal, M., El Adnani, M., \& Mourdi, Y. (2016). An augmented reality approach to integrate practical activities in e-learning systems. International Journal of Advanced Computer Science and Applications, 7(2), 107-117.

Fromkin, V., Rodman, R., \& Hyams, N. (2007). An introduction to language. Boston, MA: Thomson.

Furio, D., Juan, M., Segui, I., \& Vivo, R. (2015). Mobile learning vs. traditional classroom lessons: A comparative study. J. of Comp. Assisted Learning, 31(3), 189-201.

Godwin-Jones, R. (2016). Augmented reality and language learning: From annotated vocabulary to place-based mobile games. Language Learning \& Tech., 20(3), 9-19.

Huang, T. C. (2009). Applying augmented reality to the teaching of English nouns, verbs, and adjectives (Unpublished master thesis). Graduate Institute of e-Learning, National Changhua University of Education.

Hyso, K., \& Tabaku, E. (2011). Importance of vocabulary teaching to advanced foreign language students in improving reading comprehension. Problems of Education in $21^{\text {st }}$ Century, 29, 53-62.

Jia, J., Chen, Y., Ding, Z., \& Ruan, M. (2012). Effects of a vocabulary acquisition and assessment system on students' performance in a blended learning class for English subjects. Computers \& Education, 58(1), 63-76. 
Karimi, S. (2016). Do learners' characteristics matter? An exploration of mobile learning adoption in self-directed learning. Computers in Human Behav., 63, 769-776.

Keller, J.M. (1987). Development and use of the ARCS model of instruction design. Journal of Instructional Development, 10, 2-10.

Kim, H., \& Hyun, M. (2016). Predicting the use of smartphone-based augmented reality (AR): Does telepresence really help? Computers in Human Behavior, 59, 28-38.

Lewis, M. (1993). The lexical approach: The state of ELT and a way forward. UK: Language Teaching Publications.

Lin, B. J. (2009). A study of augmented reality on language teaching - A case study of elementary English teaching (Unpublished master thesis). Graduate Institute of eLearning, National Changhua University of Education.

Lin, J., Wang, A., \& Du, W. W. (2013). Learning English vocabulary in the Chinese context. International Journal of Language Teaching and Research, 12(1), 4-11.

Liu, T. Y., \& Chu, Y. L. (2010). Using ubiquitous games in an English listening and speaking course: Impact on learning outcomes and motivation. Computer \& Education, 55(2), 630-643.

Perry, B. (2015). Gamifying French language learning: A case study examining a questbased, augmented reality mobile learning tool. Procedia-Social and Behavioral Sciences, 174, 2308-2315.

Quiver Version. (2019). Augmented reality coloring apps (2018, December 3). Retrieved from www.quivervision.com.

Richardson, D. (2016). Exploring the potential of a location based augmented reality game for language learning. International J. of Game-Based Learning, 6(3), 34-49.

Safar, A. H., AI-Jafar, A. A., \& AI-Yousefi, Z.H. (2017). The effectiveness of using augmented reality apps in teaching the English alphabet to kindergarten children: A case study in the state of Kuwait. Eurasia Journal of Mathematics, Science \& Technology education, 13(2), 417-440.

Tsai, F. H., Yu, K. C., \& Hsiao, H. S. (2012). Exploring the factors influencing learning effectiveness in digital game-based learning. Educ. Tech. \& Society, 15(3), 240-250.

Yousafzal, A., Chang, V., \& Gani, A. (2016). Multimedia augmented mobile learning: Issues, trends and open challenges. Int. J. of Information Management, 36(5),784-792.

Zhang, S. (2018). Augmented reality in foreign language education: a review of empirical studies. J. of Technology and Chinese Language Teaching, 9(2), 116-133.

\section{APPENDIX A}

The Instructional Materials Motivation Survey (English Version)

1. The learning materials can draw my attention.

2. The materials used in class are more difficult than I originally imagine.

3. After learning from the materials, I have sense of achievement. 
4. I know very well that the learning materials are quite relevant to the English lessons I have learned.

5. I do not know or remember what I have learned in class.

6. The learning materials used in class make me engaged.

7. I think that the contents in the learning materials are worthwhile learning for students.

8. The learning materials are very important to me when I learn English.

9. It is very difficult for me to keep focusing on the learning materials because they are abstract.

10. I am confident because I feel that I can learn the lessons taught in class.

11. I look forward to learning the forthcoming materials.

12. The learning materials are quite boring and cannot draw my attention.

13. The learning materials used in class match with my interest.

14. The learning materials help me pay attention in class.

15. The learning materials are too difficult for me.

16. I am very curious about the learning materials.

17. I really enjoy learning the materials in this class.

18. Sometimes the learning materials bore me.

19. Sometimes I am amazed at what I have learned from the learning materials; I learn more than I can imagine.

20. After attending the class for a period of time, I find myself more confident.

21. In class, I feel I was motivated and I can have more sense of achievement.

22. The ways the materials were taught in class help me focused.

23. The ways the materials were taught make me bored.

24. The learning materials and the teaching make me feel fun and interesting.

25. I feel good about the learning materials.

26. The learning materials are useful for me.

27. There are many places in the learning materials I do not understand.

28. The learning materials help me learn in class and develop more confidence.

29. I enjoy the materials chosen by my teacher so much.

The Instructional Materials Motivation Survey (Chinese Version)

1. 學習教材能引起我的注意。 16 . 我對教材很好奇。

2. 在課堂上所使用的教材比我想像還困難。 17 . 我非常喜愛上課的教材。

3. 學了教材後, 我有成就感。18. 有時候我會對上課教材感到無聊。

4. 我覺得上課的教材和我的英文課所學的相 19. 有時候我會對上課教材感到驚奇, 我學習到 關。 的地方比我想像的還多。

5. 我不記得我在課堂上學到什麼。

20. 在上完一些課後, 我覺得有自信。

6. 在課程上所使用的教材讓我很投入。

7. 我認為教材內容很值得學生學習。

21. 在課堂上, 我覺得我有被激勵, 而且有成就

8. 當我在學英文時, 我認為教材很重要。 感。

9. 要讓我注意教材是很困難的, 因為他們很抽

22. 上課的教材, 能讓我更集中注意力。 象。

23. 上課的教材讓我感到無聊。

10. 我很有自信, 因為我可以學習上課的教材。

24. 上課教材讓我感到很有趣。

11. 我渴望學習先進的教材。

25. 我覺得教材很棒。

12. 教材很無聊, 所以不能引起我的注意。

26. 教材對我很有用。

13. 課堂上所使用的教材, 很符合我的興趣。

27. 我不了解很多教材的內容。

14. 教材能幫助我在課程上集中精神。

28. 上課教材能讓我更有自信。

15. 教材對我很困難。

29. 我很喜歡老師所選的教材。

International Journal of Instruction, October $2020 \bullet$ Vol.13, No.4 